\title{
The Importance of Trade for Reverend E. M. Lijadu and the Evangelist Band Mission
}

\author{
Joseph Osuolale Ayodokun \\ ERC Research Team Member \\ University of Ibadan, Nigeria \\ josephayodokun@gmail.com
}

\begin{abstract}
This article discusses the activities of the Evangelist Band Mission (EBM), led by Reverend E. M. Lijadu from 1901 to his death in 1926, in the coastal Ikale and Ilaje areas south of Ondo. The EBM whih operated in close association with the Church Missionary Society, but was financially independent and self-supporting. Trade was an important factor in ensuring its economic viability. The article also suggests that the availability of goods associated with Christianity, such as books, Western dress, and certain tools, was a factor that contributed to the adoption of Christianity because it allowed individuals to 'try out' forms of consumption associated with Christianity in a positive and yet containable way.
\end{abstract}

\section{Introduction}

At the beginning of the nineteenth century, the major form of external contact that sub-Saharan Africa had with the wider world involved trading slaves and tropical produce with European and Arab countries. ${ }^{1}$ Increases in the volume of trade later in the century and the eventual colonization of Africa coincided with Christian missionary enterprise. ${ }^{2}$ Although Christian missionary

1. Elizabeth Isichei, A History of Christianity in Africa: From Antiquity to the Present (London: Society for Promoting Christian Knowledge, 1995).

2. Viera Pawlikova-Vilhanova, "Christian Missions in Africa and their Role in the Transformation of African Society," Asian and African Studies, 16.2 (2007): 249-260. 
work in Africa can be traced back to the fifteenth century, the success of early missionaries was very limited until the abolition of the slave trade, and the rise of an evangelical movement among Europeans in the eighteenth century. ${ }^{3}$

From its inception, Christian missionary work in Africa experienced great difficulties. The tropical climate caused illness and death and missionaries met resentment and hostility from local communities. ${ }^{4}$ Nevertheless, Christian missionary work expanded, particularly after William Carey's pioneering essay, An Enquiry into the Obligations of Christians to Use Means for the Conversion of the Heathens (1792). ${ }^{5}$ Efforts to convert Africans through the establishment of schools and health facilities paid dividends. ${ }^{6}$ By such means, missionary work integrated itself into African society and opened the continent to a huge flow of commerce, and eventual colonization. ${ }^{7}$

Although trade is often referred to as an important element in the spread of Islam, many Africans with early access to missionary education were highly involved with the trade in European goods, serving as distributors and agents. ${ }^{8}$ When African societies embraced Christianity, they often also embraced European goods and technologies. Beyond the ideas and practices directly associated with Christianity, new ways of living and doing things contributed to social transformation.

One such agent of this cultural change was Emmanuel Moses Lijadu (1862-1926), who is best known for his formation of the independent Evangelist Band Mission which carried out a lot of missionary work south of Ondo. Formerly a member of the Church Missionary Society, Lijadu left the CMS in 1901 to lead a highly successful, self-funded evangelistic group to the areas south of Ondo, which he supported through trade in goods, an enterprise that was largely associated with Christianity and modernization. Looking at an inventory list of goods sold by Lijadu in three stores in Ondo and south of Ondo in 1929, this article argues that the sale of modern goods allowed many people to familiarize themselves with Christianity in a positive and yet manageable way.

3. A.U. Agha, Early European Missions to West Africa (Enugu: Calvaryside Printing \& Publishing Co., 1997), 56.

4. Adrian Hastings, The Church in Africa 1450-1950 (Oxford: Clarendon Press, 1996).

5. William Carey, An Enquiry into the Obligations of Christians to Use Means for the Conversion of the Heathens (1st edn, 1792; Didcot: The Baptist Missionary Society 1991).

6. Bengt Sundkler and Christopher Steed, A History of the Church in Africa (Cambridge: Cambridge University Press, 2000), 84-85.

7. Pawlikova-Vilhanova, "Christian Missions in Africa," 249-260.

8. Roland Oliver and Anthony Atmore, Africa since 1800 (1st edn, 1967; Cambridge, Cambridge University Press, 2004). 


\section{E. M. Lijadu before the formation of the Evangelist Band Mission}

As the son of one of the early converts to the Anglican Christian mission in the town of Abeokuta, Emmanuel Moses Lijadu graduated from the renowned Teachers' Training Institute in Abeokuta in 1885 and later worked as a teacher, a catechist for the Ondo Anglican mission, and a deacon (1894). Lijadu's healing powers, which came to the fore during an influenza epidemic in 1895, meant that he became a pioneering evangelist and teacher. When Lijadu was assigned to the Yoruba Mission in 1896, Bishop Charles Phillips was confident that he could implement the CMS's objectives in the Ondo Episcopal area. The first of these objectives was the organization of the Ondo church along the lines of a memorandum submitted in 1861 by a Reverend Jones explaining that it was "expedient for native converts to be trained as early as possible upon a system of self government and of contributing to the support their own native teachers". 9 To achieve this, Lijadu formed self-support groups for Christian converts in Ondo.

The other objective was to instil greater discipline within the Ondo Christian community, particularly with regards to preventing male converts from marrying non-Christian women. It was also Lijadu's responsibility to encourage Christian men in the church to practice monogamous Christian marriages as prescribed by the Church of England. Lijadu's third assignment was to spread Christianity beyond Ondo to towns including Ado, Owo, Idanre, Akure and Ise. The Bishop advised that Lijadu should work among native converts carefully so as not to aggravate them but rather to draw them towards Christianity willingly. ${ }^{10}$

In 1898 Lijadu gained the permission to form the Evangelist Band Mission that travelled from Ondo to establish Christianity in numerous coastal communities in the Ikale and Ilaje coastal region. ${ }^{11}$ The geographical nature and size of the region required great mobility on the part of Lijadu and the Evangelist Band. The strategy did not require great financial outlay, other than free will offerings from the local church. However, the experience as a travelling missionary also led Lijadu to become increasingly critical of existing missionary strategy, which he felt did not have enough roots in Yoruba culture. When demands for higher salaries were rebuffed by CMS administrator Thomas Harding, Lijadu also came to believe that missionaries need not rely on offerings from converts.

9. The Kenneth Dike Library, University of Ibadan: Lijadu Papers (hereafter Lijadu Mss): Box 2: S.C. Phillips to E.M Lijadu, 8 Dec 1896.

10. Ibid.

11. Annual report of Okitipupa, 1930 O.P 120C National Archives Ibadan; Lijadu Mss: Box 2: 1905 Journal of E.M Lijadu, p. 98; 1902 Journal of EM Lijadu, 90-93. 
Working independently of the CMS from 1901, Lijadu and his Evangelist Band Mission enjoyed more success in spreading Christianity across the Ondo region than their white counterparts. ${ }^{12}$ Lijadu's footprint remains evident today across the coastal communities where he and the Evangelist Band Mission worked. This work eventually earned him the accolade of 'Ajinhinrere lofe l'ode Ondo' (the unpaid evangelist of Ondo).

The region where Reverend Lijadu was most active is located in the southern part of what is today Ondo State (formerly Ondo Province). The area is mainly inhabited by the Ikale and Ilaje, two sub-groups of the Yoruba. The Ikale people, most of whom were farmers by the early twentieth century, occupied about half of the region. In the south, the Ilaje people lived along the coast on various creeks forming a fishing and mat-making community. Their main rural settlements were in large part comprised of houses made of mud and thatch; a minority of wealthier inhabitants occupied houses made of mud walls and corrugated roofs.

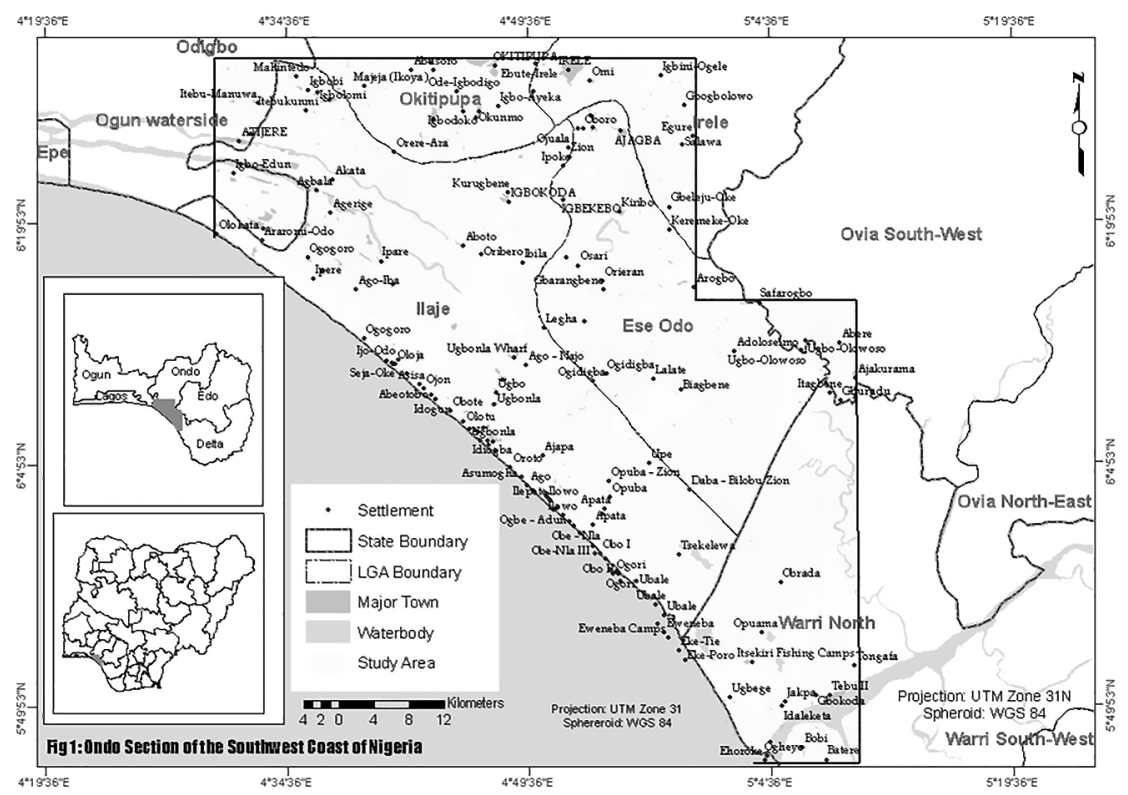

Figure 1: Ondo Section of the Southwest Coast of Nigeria. Source: Author's map.

12. Jacob Kehinde Coker, 'Peter Adebiyi', in Joseph Akinyele Omoyajowo, ed., Makers of the Church in Nigeria (Lagos: CSS Bookshop Limited, 1995). 


\section{The Evangelist Band Mission (Ijo Ajihinrere lofe I'Ode Ondo)}

Lijadu's separation from the Church Missionary Society in 1901 to start an independent mission was based on his belief that he would spread Christianity more effectively by establishing firm roots in indigenous culture. In the Evangelist Band, Lijadu brought together a coalition of like-minded converts who thought that there was a need to present the gospel to the native population in a more relatable manner. His idealistic intent is illustrated by a diary entry from February 1901:

The possibility for good, which may belong to the unpaid native ministry working in whatever capacity alongside the paid. Such unpaid ministry as may eventually be found to be a fortunate auxiliary to the future church in Yoruba land towards making Christianity indigenous to the country towards making it the strongest and purest religion in the country and towards hastening its spread over the many thousands yet unreached. Those possibilities for good have for some years past been pouring down upon my mind in as it were continual torrents of thoughts until lately I expressed them to the executive council in a tangible form signifying my earnest desire to speculate for missions on the lines of those possibilities. ${ }^{13}$

Lijadu also believed that missionaries should be self-funded, working voluntarily across Yorubaland. He believed that ministers should live by example and not solely depend upon the congregation for their funding. In principle, this conformed to the view of the founding fathers of the CMS mission, and in any case, the CMS's executive council expressed support for Lijadu's idea to set up a self-supporting evangelistic mission that would collaborate with existing CMS work in the Ondo Episcopal area. Therefore, although the Evangelist Band Mission operated independently from the CMS, it had a strong affinity with the CMS mission. With only few exceptions, Lijadu preached and taught Anglican beliefs and practices, and he and his wife remained members of St Stephen's congregation in Ondo.

At first, the Evangelist Band Mission was mainly active in Ondo itself, where within a few years a church was built that would become the Band's headquarters. In the church, the native volunteer evangelists, from Ondo and other communities in the interior, also received their training. In addition to teaching the Bible's contents, the native student evangelists were trained in how to present the gospel to those who had not come into contact with it through plays, conversations, and music. Lijadu also insisted that all members

13. Lijadu Mss Box 2: Journal of E.M Lijadu, 1901, 12. 
should (eventually) be able to support themselves by learning a trade that was both useful and compatible with Christianity.

Membership of the Band Mission was open to ministers of God in Ondo and its region, church pastors in Ondo and its region, and student evangelists in training in accordance with the regulation of the Evangelist Band Mission. Following the practice of the Anglican Church of the time, that meant that all band members were male. However, some members brought their (Christian) wives, and insofar as these wives followed the Evangelist Band, they should also be considered missionaries.

Lijadu insisted that all band members must be baptized in the mission church. This was important because the band itself constituted a close and intensely Christian community. To maintain the spiritual commitment and enthusiasm that was vital to the success and cohesion of the band, the activities of the Band Mission included daily morning and evening prayer meetings. While membership was free, all members had to comply by the rules set up by Lijadu and the Ikomo (the executive council of the Evangelist Band Mission), and they were encouraged to offer donations towards the work of the Evangelist Band from any income they had.

At the Band's inaugural meeting in Ondo on New Year's Day 1901, it was decided that the society should consist of three sub-groups; the elders, the teachers and the students. The executive council, numbering twelve, was formed of Elders and the Teachers deemed to be committed evangelists. The Band's officers were selected among the elders and formed a hierarchy with Christianized Yoruba titles including the Bale Ajinhinrere (Governor of the Evangelists), Are Bale Ajinhinrere (Deputy Governor of the Evangelists), and other posts including the Otun Ajinhinrere, Osi Ajinhinrere, Asiwaju and Abese. Among the teachers, a slightly different hierarchy was formed with officers including the "Oga Iwe ati awon oluranlowo re" (the Principal and other teachers that assisted in the training of the student evangelists) and the "Oga Ona ati awon Oluranlowo re" (the Administrator/Registrar and other band members that assisted in the running of the training school and facilities).

Students were apprenticed in a manner that combined both practices of the CMS and local understandings of how people learnt professions and discipline. Newcomers could apply to the Oga Iwe (Principal of the Evangelist Band Mission Training School) to join the Evangelist Band Mission at fixed times, namely two weeks before the first day in a new year or two weeks before the Holy Trinity of the year. Students were expected to spend at least two years in school, where they would be examined six times. But in line with Lijadu's ambition to form an economically viable missionary group, every student evangelist must also have a trade (or be ready to learn one while in training to become an evangelist), to support himself while in the field. If a student was 


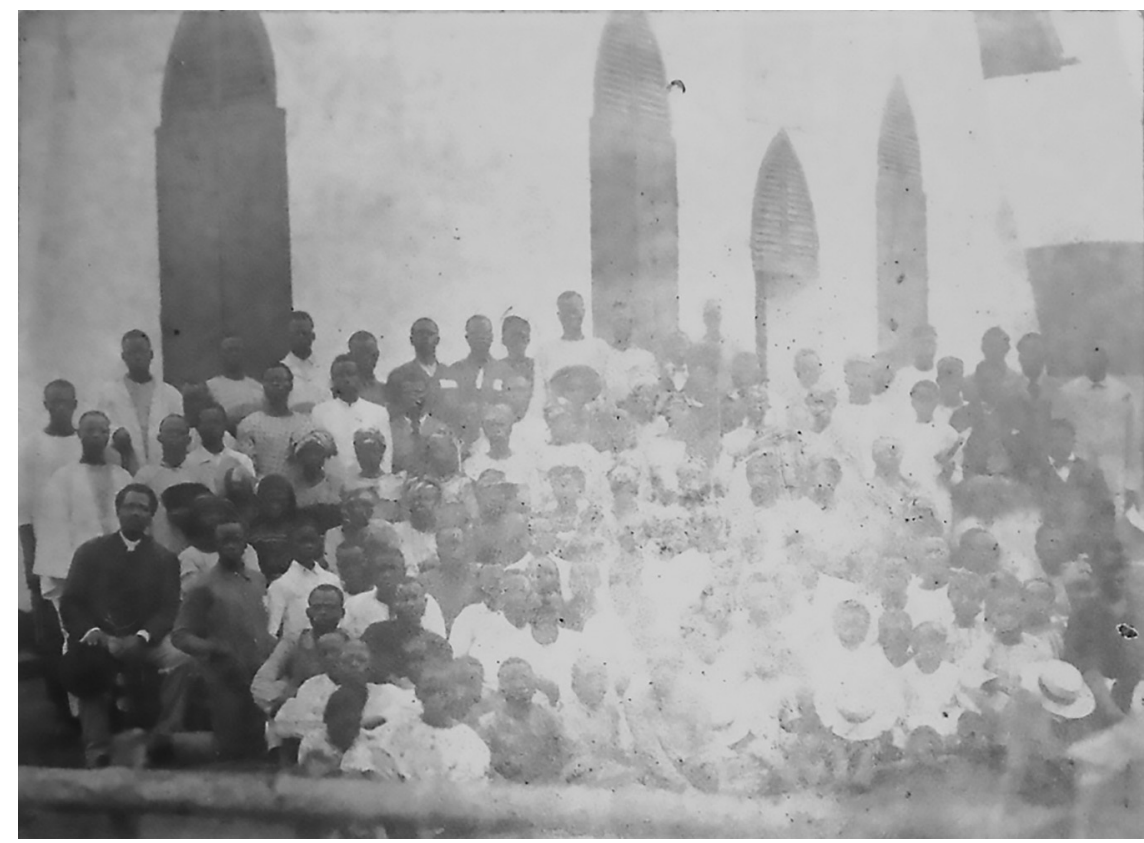

Figure 2: The Evangelist Band with a church auditorium in the background, location unknown, 1918. Source: Author's image.

married, his wife would also receive special training to support their missionary work.

Work considered appropriate for student evangelists was mainly artisanal and it included traditional professions such as basket making, weaving, and mat making. However, many professions were also closely linked to forms of production and consumption that were typically associated with European influence, such as metal work, carpentry, tailoring, hand fan making, leather work, cane chair making, sieve making, block laying and building work. For example, while the production of metal tools and art had a long local history, the metal work taught to the students of the Band Mission also included working with modern nails, nuts and bolts, and with bicycles. Similarly, tailoring could include both traditional and modern dress-making.

Student evangelists had different roles and titles depending on their ability to look after themselves. Those who were able to take care of themselves were categorized as Devotees of the Gospel while those that were cared for by the Evangelist Band Mission leader were only called Apprentices of the Gospel. Apprentices of the Gospel had to abide by whatever the Principal, i.e. Lijadu, asked them to do, but Devotees of the Gospel could come to training from home, based on clearly set out arrangements that considered 
how they might best combine their business and the task of learning and duties of ministry.

In order to qualify for the training to be received, student evangelists must agree to serve the Evangelist Band Mission after the completion of study at any station they might be posted to, either for free or at any rate the Band Mission could afford to pay. While individuals who desired to obtain further training in theology were usually sent to the CMS mission school in Oyo, they were not exempted from this obligation. The punishment for bad behavior, both among students and other members, was payment of fines and if persistant, dismissal from the Evangelist Band.

\section{Financing the Evangelist Band}

At their inaugural meeting, the members of the Evangelist Band Mission agreed that all its operations would be self-funded by themselves, and that it would also accept donations for certain funds. ${ }^{14}$ These funds included the Evangelist Fund, the Church Bell Fund, the Thanksgiving Fund, an Educational Fund towards education of band members' children and evangelist training, the Sunday service giving of tithes and offerings, the Ministers' welfare fund and a Special fund for special events and programmes of the Band. ${ }^{15}$ The funds attracted a significant income as many members and converts faithfully contributed to them. Also, student evangelists who were cared for by Lijadu while still in training contributed the income from any artisanal products they sold to the band's funds. ${ }^{16}$

Later a propitiation fund was set up for the care of the needy among the Band Mission members and their congregations, focusing on sickness, invalidity, and victims of slavery or pawnage. The introduction of the propitiation fund and the reasons for which the fund was instituted is a pointer to the prevailing social-economic situation of the coastal communities within which the Evangelist Band were operating then. The Evangelist Band Mission's commitment to redeeming enslaved and pawned individuals - and to accepting these individuals into their fold subsequently - meant that it was embraced by many 'ordinary' people, who might be affected by these practices either directly or indirectly. Given that the Evangelist Band Mission operated long after the establishment of colonial rule and the formal abolition of slavery, the impor-

14. Lijadu Mss: Box 2: Journal of E.M Lijadu, 1901, 18-20.

15. Lijadu Mss: Box 3: Journal of E.M Lijadu, July- December 1904, 100-103.

16. Lijadu Mss: Box 3: Journal of E.M Lijadu, 1899-1900, 17. A Band of sewing women was formed to produce clothes that could be sold. 
tance of this practice also illustrates the pervasiveness of these practices in some parts of southwest Nigeria. ${ }^{17}$

The Evangelist Hall at Ode Ondo was solely financed by Lijadu, though founding members of the Evangelist Band Mission provided labor and materials. ${ }^{18}$ By 1918 , with little or no support from the outside world, the Evangelist Band Mission had established itself in almost every Ikale and Ilaje town. In each community, there was either a church or an auditorium under construction, often in addition to a primary school. As schools began to become self-supporting and then profitable, the mission was responsible for most of the area's elementary education by 1934, even though Lijadu had died by then.

Locally raised funds were largely spent in the area where they were raised. For instance, in 1919 the total propitiation fund raised at Siluko church was $£ 7.10$ s.6d. and the total sum of what was given to local assembly members was $£ 7.2$ s. $6 \mathrm{~d} .{ }^{19}$ For special projects, like the building of a church auditorium, it was the first duty of the congregation concerned to raise money, but great support was usually forthcoming from other churches and individuals who belonged to the Band.

Despite Lijadu's insistence on members' ability to offer a trade, and despite income from local schools, trade soon became the principal means by which the Evangelist Band Mission sustained itself. By the early twentieth century, most of the inhabitants in the Ondo, Ikale and Ilaje regions where Lijadu worked were rural and agrarian. Many of them had a desire for foreign products, whose consumption allowed them to distinguish themselves from others, whether through the use of bicycles, the wearing of 'modern' clothes, or by building a brick house with a roof made of corrugated iron. As in other parts of early colonial Nigeria, these goods were marks of wealth and distinction because they originally came from Europe. For the same reason, these goods and fashions were associated both with Christianity and with modernity.

Lijadu began trading on a small scale by selling books during his journeys. Lijadu was an intellectual in his own right, and he had published a pioneering book on Ifa divination and several works on Yoruba history and mythology, partly in a personal engagement with non-Christian practices and partly in order to increase the understanding of local (Yoruba) culture among non-Yoruba missionaries. By selling these books, as well as books and printed materials

17. While so far, I have only come across one case of redeemed slavery in the Lijadu papers, I have only begun to make inroads into this sizeable collection. Pawnship, which often affected the children of parents who were in debt, was more widely practiced.

18. Lijadu Mss: Box 2: Journal of E.M Lijadu 1901, 23-24.

19. Lijadu Mss: Box 2: "The Report of the Churches under the Evangelist Band Contribution into the Propitiation Fund and How it is Spent," undated. 
obtained through the Church Missionary Society or from the publisher James Townsend, he hoped both to fund his missionary endeavors and to satisfy the desire for written texts among those who had learnt to read as part of their conversion.

However, very quickly Lijadu went on to provide goods to people in the Ikale and Ilaje region that were otherwise unavailable. Eventually, Lijadu opened stores in three locations. Most of the products were sourced from markets in Ondo, or from major European traders. As the stores expanded, they offered products from British companies such as the Millers Brothers, George Will and Son, and the Lever Brothers. ${ }^{20}$ The stores' stock and sales records (see appendix) show that Lijadu's stores were a thriving business that enabled them to spread their influence across the coastal communities of Yorubaland. An inventory of the stores taken in April-June 1925 illustrates the success of Lijadu's strategy: the total value of the goods in the stores was over $£ 287$ ( $£ 15,760$ in 2016 prices), then as now a significant sum in terms of its buying power in the area.

Lijadus's success suggests that the importance of trade, both in goods directly associated with Christianity, such as books and stationery, and in other European-produced goods, has been much neglected in the study of Christianity in Africa. One reason for this is probably that most academic research has focused on European missionaries or European-dominated missionary societies, which did not prioritize this form of income-generation. Indigenous Christian missionary work however is often closely linked to trade, and this may have contributed to the eventual success of Christianity in ways that have not yet been set out clearly.

\section{Christian Commodities sold in Lijadu's Shops}

The combination of missionary work and trade linked conversion to access to new commodities. By exploring what goods were offered by Lijadu, we can see what kinds of consumption were subtly associated with Christianity through his missionary practice. Also, because Christian or Christian-owned shops, unlike schools or churches, did not discriminate among buyers, they allowed people of all religious background to access the things associated with the new religion. An inventory of the Evangelist Band's shops in 1929, three years after his death, suggests that the sale of modern goods in a missionary's shop subtly encouraged understandings of Christianity as the appropriate religion for those who had use for them (see Appendix I).

20. Lijadu Mss: Box 2: George Will and Sons to E.M. Lijadu, 24 June 1920. 
The Evangelist Band's shops were often the first local outlets for European goods in the Ikale and Ilaje areas. As a result these goods were often associated with Christianity. Clearly, stationery and books were associated with the skills of reading and writing that many converts acquired on their journey towards Christianity. Equally, the inventory of these stores suggests a close link between Christianity and other imported or foreign-influenced goods, such as provisions, clothes, and hardware. While European clothing was originally closely linked to Christianity, the sale of thread and needles also suggests that sewing was similarly associated. It is very likely that in many Ikale and Ilaje communities, fashion-consciousness and Christianity were seen as closely related.

Fashion must have been important in other ways too: the popularity of certain goods may have rested entirely on its foreignness or novelty. For example, the sale of conserved sardines and salmon in Ilaje, a part of coastal Nigeria famous for its fishing industry and a great exporter of fish, and even in nearby Ikale, is difficult to explain in other terms. Like canned meat, these fish conserves were far more expensive than local fish, and were mainly bought for conspicuous display and consumption on special occasions.

Finally, the predominance of hardware - one of the largest categories of commodities offered by Lijadu and the Band Mission - suggests that the tools and fixings provided by them associated Christianity, among other things, with the houses or pieces of furniture that were built to replace old habitats taken down with sledge hammers, and that were built with saws, hammers and nails; with the bicycles that needed new spokes, handle-bar bolts or chain balls; and with clean-smelling oil or gas lamps rather than smoky palm oil burners.

By establishing a direct link between Christianity and the consumption of modern goods, then, Lijadu and the Evangelist Band Mission rooted Christianity in local practice in ways that went far beyond the popularity of his band's songs and sermons. The broad range of his activities suggested to his customers and would-be followers that Christianity, was much more than 'just' a religion: it was a way of life. And yet, unlike missionary schools and churches in Ondo, and unlike even Lijadu's own missionary efforts, the sale of individual goods also allowed what churches and missionaries themselves did not countenance, namely partial commitment, or 'playing at' being a Christian.

While the shops of the Evangelist Band Mission allowed people to experience some of the benefits often associated with Christianity without conversion, they also invited individuals to act like Christians - one tool, one piece of clothing, one tin of sardines at a time. The fact that Christianity has not only become the dominant religion of the area, and that many people understand 
Christianity and modernity as two sides of the same coin, suggests that this was a successful strategy.

\section{Summary and Conclusion}

This article has provided some insight into the life of Emmanuel Moses Lijadu, an indigenous missionary first with the Church Missionary Society and then on his own accord. Tracing the set-up and the material and conversionary success of Lijadu's Evangelist Band, the article argues that trade was an important aspect of Christianization, because it supported missionaries, and because it made conversion easier by giving would-be-converts the possibility of trying the new religion in a limited way. Looking at an inventory list of goods sold by the Evangelist Band Mission in three stores in Ondo and south of Ondo in 1929, this article argues that the sale of modern goods allowed many people to familiarize themselves with Christianity in a positive and yet manageable way.

The result of the Evangelist Band's missionary work within eight years of the band's foundation was reported in handbills distributed in London in the year 1908 during the Pan Anglican Mission Congress held in the United Kingdom. The achievements of the Evangelist Band were stated to include self-supporting Churches in several towns and villages in the country, the opening of a book-room in Ode Ondo to stimulate education, the establishment of ten churches and congregations, and the gathering of 800 Christian of whom 160 persons were baptized and communicants. ${ }^{21}$

21. Lijadu Mss: Box 2: "Mission of the Evangelists' Band Ondo, Western Equatorial Africa: A Handbill distributed during the Pan Anglican Congress of 1908 in London," July 1908. 


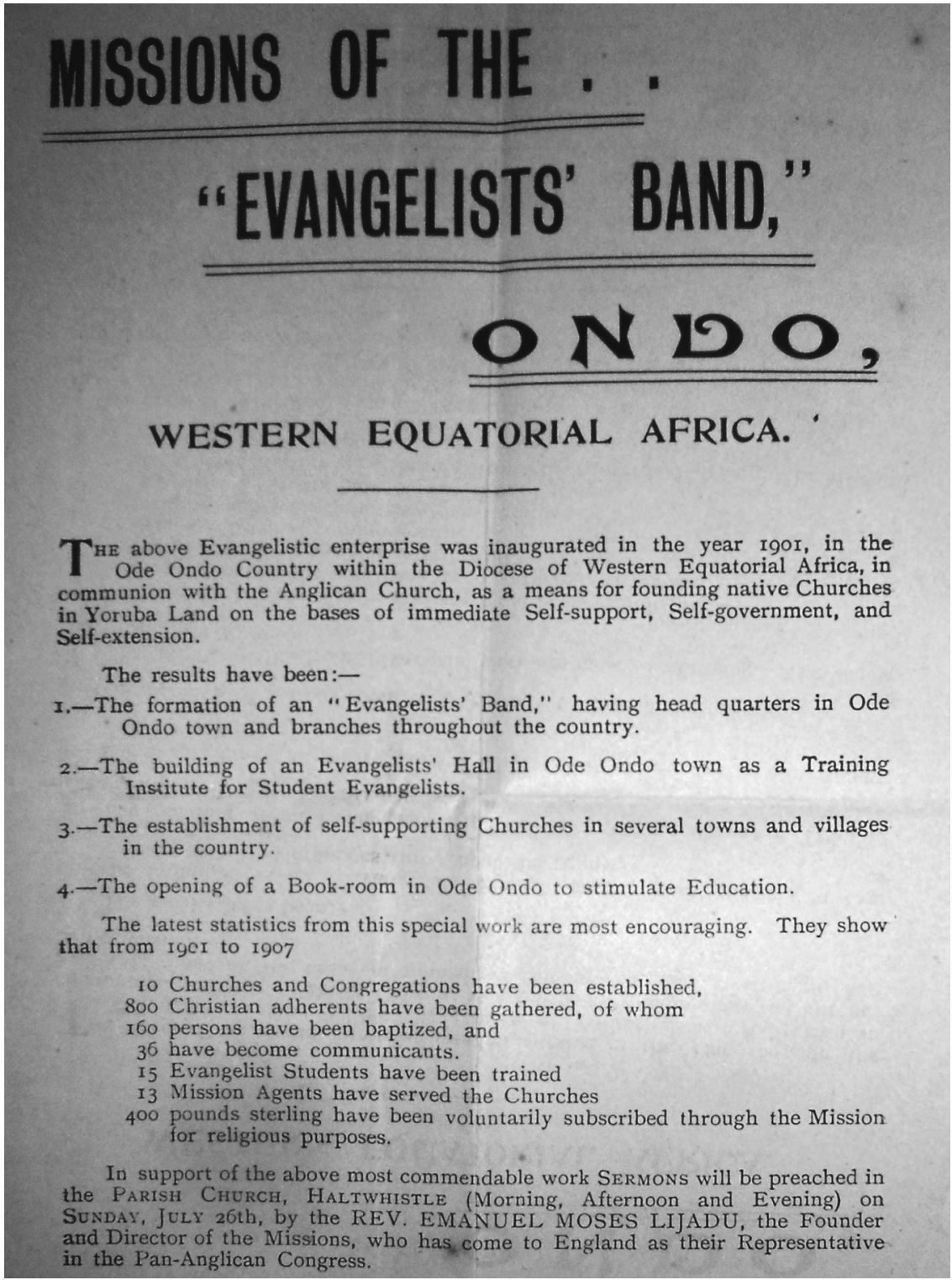

Figure 3: A Handbill distributed during the Pan Anglican Congress of 1908 in London, July 1908. Source: With permission of the University of Ibadan, Kenneth Dike Library, Lijadu Mss: Box 2: Mission of the Evangelists' Band Ondo, Western Equatorial Africa. 
Appendix: Inventory of Lijadu's Stores, April - June 1929

\begin{tabular}{|c|c|c|}
\hline Items & Price per unit & Quantity Stocked \\
\hline \multicolumn{3}{|l|}{ Tools } \\
\hline Hand Saw 30" & $12 / 6$ & 3 \\
\hline Hand Saw 24" & $10 / 6$ & 8 \\
\hline Hand saw skew hatch 2383 & $12 / 6$ & 5 \\
\hline Tenon Saw & $7 / 6$ & 6 \\
\hline Ratchet Brace & $15 /-$ & 3 \\
\hline Jennings August & $2 / 6$ & 12 \\
\hline Pit saw & $60 /-$ & 7 \\
\hline Brace gimlet & $1 /-$ & 6 \\
\hline Spoke & $5 / 6$ & 6 \\
\hline Wood shine & $4 / 6$ & 1 \\
\hline Different types of Chisel & 5/- average price & 10 \\
\hline $\begin{array}{l}\text { Double Plane Iron of different } \\
\text { gauges }\end{array}$ & $8 /-$ & 24 \\
\hline $\begin{array}{l}\text { Single plane iron of different } \\
\text { gauges }\end{array}$ & $6 / 6$ & 61 \\
\hline Pincers & $4 /-$ & 6 \\
\hline Screw drivers & $1 / 6$ & 6 \\
\hline Grooves and Tongues & $16 / 6$ & 3 \\
\hline Centric beads & $11 / 6$ & 2 \\
\hline Big oil can & $2 /-$ & 2 \\
\hline Level spirit & $2 / 6$ & 1 \\
\hline Small housing stone & $2 /-$ & 14 \\
\hline Iron plane blocks & $6 /-$ & 7 \\
\hline Jack plane & $16 / 6$ & 2 \\
\hline Smooth plane & -- & -- \\
\hline Dutch plane & $7 / 6$ & 2 \\
\hline Small oil can & $6 \mathrm{~d}$ & 8 \\
\hline Centric bit & $2 / 6$ & 36 \\
\hline Hammer & $4 /-$ & 13 \\
\hline Iron spoke shane & $7 / 6$ & 3 \\
\hline Chest lock of different sizes & $1 / 6$ & 56 \\
\hline Triplex saw & $8 / 6$ & 1 \\
\hline Leather and figure punches & $2 /-$ & 1 \\
\hline
\end{tabular}




\begin{tabular}{|c|c|c|}
\hline Turning webs web of different sizes & $5 / 3$ & 55 \\
\hline Iron plough & $42 /-$ & 11 \\
\hline Rim lock & $5 /-$ & 9 \\
\hline Sledge hammer & $10 / 6$ & 26 \\
\hline Big oil store & $4 /-$ & 9 \\
\hline Gimlet of different sizes & $1 / 3$ & 31 \\
\hline Wire nails of different sizes & $6 \mathrm{~d}$ & 59 \\
\hline Zinc nails & $1 /-$ & 13 \\
\hline Washers & $1 /-$ & 18 \\
\hline Big bench Vise & $25 /-$ & 1 \\
\hline Hand vise & $7 / 6$ & 4 \\
\hline Sand papers & $4 \mathrm{~d}$ & 15 \\
\hline Files of different sizes & $2 /-$ & 48 \\
\hline \multicolumn{3}{|l|}{ Honda Belly rings } \\
\hline Coal Tar & $1 / 2$ & - \\
\hline Tin snips & $4 /-$ & 2 \\
\hline Nippers & $4 / 6$ & 5 \\
\hline Tin Cutter & $1 / 6$ & 6 \\
\hline Small bench vice & $7 / 6$ & 2 \\
\hline Pliers & $6 / 6$ & 3 \\
\hline Saw set & $4 / 6$ & 4 \\
\hline Pit saw file & $1 / 6$ & 12 \\
\hline Shuttle & $5 /-$ & 3 \\
\hline Razor & $1 /-$ & 64 \\
\hline Scissors & $2 /-$ & 10 \\
\hline Tape & $6 \mathrm{~d}$ & 2 \\
\hline Vasol oil & $1 /-$ & 2 \\
\hline Pedal rubber & $1 /-$ & 4 \\
\hline Pedal caps & $1 /-$ & 10 \\
\hline Handle bar lock & $2 / 6$ & 5 \\
\hline Ball races & $2 / 6$ per set & 6 set \\
\hline Small carriers & $2 / 6$ & 5 \\
\hline Tyre cushion & $6 \mathrm{~d}$ & 8 \\
\hline Spokes 26" & $1.5 \mathrm{~d}$ & 78 \\
\hline Chain pins & $1 /-$ & 10 \\
\hline Handle bar bolt & $4 /-$ & 11 \\
\hline
\end{tabular}




\begin{tabular}{|c|c|c|}
\hline Spoke keys & $1 /-$ & 11 \\
\hline Front cones & $9 \mathrm{~d}$ & 11 \\
\hline Back cones & $1 /-$ & 11 \\
\hline Head locks & $3 / 6$ & 4 \\
\hline Footstep & $2 /-$ & 4 \\
\hline Cable back brake & $10 / 6$ & 3 \\
\hline Tools bag & $2 /-$ & 8 \\
\hline Chain adjuster & $1 /-$ & 4 \\
\hline Screw nub & $1 /-$ & 12 \\
\hline Handle bar ring & $2 /-$ & 5 \\
\hline Bracket cups & $2 /-$ & 19 \\
\hline Pumps & $2 / 6$ & 8 \\
\hline Back wheel & $12 / 6$ & 3 \\
\hline Enamel & $2 / 6$ & 2 \\
\hline Repair outfit & $6 \mathrm{~d}$ & 2 \\
\hline Solution & $1 /-$ & 12 \\
\hline Free wheel & $6 /-$ & 2 \\
\hline Shifting spanner & $2 /-$ & 9 \\
\hline Ordinary handle grip & $6 \mathrm{~d}$ & 6 \\
\hline Rubber handle grip & $1 /-$ & 16 \\
\hline Crank colters & $1 /-$ & 11 \\
\hline Cycle chain & $5 /-$ & 4 \\
\hline Cycle bells & $9 \mathrm{~d}$ & 6 \\
\hline Outer cover & $5 /-$ & 25 \\
\hline Inner timble & $2 / 6$ & 8 \\
\hline Back spindle & $1 / 6$ & 11 \\
\hline Front spindle & $1 / 3$ & 9 \\
\hline Spokes $28 "$ & $1.5 \mathrm{~d}$ & 116 \\
\hline Empty tins carbide & $6 \mathrm{~d}$ & 23 \\
\hline Pads holders & $1 /-$ & 11 \\
\hline Brake pads & $6 \mathrm{~d}$ & 15 \\
\hline Right crank & $5 /-$ & 1 \\
\hline Football adapter & $1 /-$ & 6 \\
\hline Nuts & $6 \mathrm{~d}$ & 146 \\
\hline Steel balls & $1 / 2 \mathrm{~d}$ & 244 \\
\hline Back brake & $10 / 6$ & 1 \\
\hline
\end{tabular}




\begin{tabular}{|c|c|c|}
\hline Front brake & $7 / 6$ & 1.5 \\
\hline Lever cone spanner & $9 \mathrm{~d}$ & 19 \\
\hline Four hole spanner & $1 /-$ & 12 \\
\hline Football cases & $10 /-$ & 6 \\
\hline Mudguard & $3 /-$ & 11 \\
\hline Carrier with stand & $5 / 6$ & 2 \\
\hline Pairs Gents pedals & $5 /-$ & 11 \\
\hline Pedal Spindle & $1 / 6$ & 11 \\
\hline Bracket bolters & $1 /-$ & 6 \\
\hline Bracket axle & $2 /-$ & 5 \\
\hline Left crank & $3 / 6$ & 3 \\
\hline Gas lamp & $7 / 6$ & 4 \\
\hline Oil Lamp & $3 /-$ & 1 \\
\hline Gas Burner & $1 / 6$ & 11 \\
\hline Pump connection & $1 /-$ & 9 \\
\hline Carbide & $1 /-$ & 31 \\
\hline \multicolumn{3}{|l|}{ Sundry Goods } \\
\hline Bucklers & $1 \mathrm{~d}$ & 90 \\
\hline Gents hose & $3 /-$ & 9pairs \\
\hline Black thread & $6 \mathrm{~d}$ & 12 \\
\hline Khaki thread & $6 \mathrm{~d}$ & 7 \\
\hline Khaki slip & $4 /-$ & 8 \\
\hline Boot polish & $3 /-$ & 2 \\
\hline Rain cap & $6 \mathrm{~d}$ & 12 \\
\hline Machine needle & $3 d$ & 135 \\
\hline Canvas needle & $1 / 2 \mathrm{~d}$ & 26 \\
\hline \multicolumn{3}{|l|}{ Provisions } \\
\hline Sardines & $4 \mathrm{~d}$ & 100 \\
\hline Salmon & $9 d$ & 20 \\
\hline Canned beef & $9 \mathrm{~d}$ & 46 \\
\hline Lipton tea & $1 / 6$ & 11 \\
\hline Coffee & $1 / 6$ & 4 \\
\hline Tomatoes & $2 d$ & 84 \\
\hline Candles & $1 /-$ & 24 \\
\hline
\end{tabular}




\begin{tabular}{|c|c|c|}
\hline Baking powder & $1 /-$ & 1 \\
\hline Unsweetened milk & $6 \mathrm{~d}$ & 84 \\
\hline Cigarette bunch & $2 / 6$ & 11 \\
\hline Pipes & $1 /-$ & 15 \\
\hline Epsom salt & $1.5 \mathrm{~d}$ & 115 \\
\hline Castor oil & $6 d$ & 6 \\
\hline Senna leaves & $6 \mathrm{~d}$ & 11 \\
\hline Ammonia & $2 / 1$ & 11 \\
\hline Quinine pills & $3 /-$ & 9 \\
\hline Ear drops & $3 /-$ & 6 \\
\hline Back and kidney pills & $3 /-$ & 4 \\
\hline Tissues & $25 /-$ & 1 \\
\hline Salt peptic & $6 \mathrm{~d}$ & 11 \\
\hline Embrocating & $2 / 6$ & 5 \\
\hline Eye lotion & $3 / 6$ & 8 \\
\hline Alum & $6 \mathrm{~d}$ & 15 \\
\hline Analgesic balm & $2 /-$ & 6 \\
\hline Eucalyptus oil & $1 /-$ & 5 \\
\hline Elixir Arena & $5 /-$ & 5.5 \\
\hline Debility & $5 /-$ & 1 \\
\hline Heart drops & $5 /-$ & 5 \\
\hline Sloan liniment & $2 /-$ & 6 \\
\hline Worm powder & $1 /-$ & 12 \\
\hline Feeding bottle & $2 / 6$ & 3 \\
\hline Talcum powder & $2 \mathrm{~d}$ & 4 \\
\hline Long hand spectacle & $3 / 6$ & 7 \\
\hline Curl speet & $5 / 6$ & 1 \\
\hline Goggles & $2 / 6$ & 3 \\
\hline \multicolumn{3}{|l|}{ Stationery } \\
\hline Rulers & $3 \mathrm{~d}$ & 15 \\
\hline Writing pad & $1 / 6$ & 15 \\
\hline Letter file & $3 /-$ & 3 \\
\hline Eraser & $1 \mathrm{~d}$ & 59 \\
\hline Pen holder & $3 \mathrm{~d}$ & 9 \\
\hline School card & $1 \mathrm{~d}$ & 68 \\
\hline
\end{tabular}




\begin{tabular}{|c|c|c|}
\hline Blotters & $1 \mathrm{~d}$ & 9 \\
\hline Slate & $1 / 2 \mathrm{~d}$ & 76 \\
\hline Pencil & $1 \mathrm{~d}$ & 78 \\
\hline Lead pencil & $3 \mathrm{~d}$ & 78 \\
\hline School register & $2 / 6$ & 1 \\
\hline Relief & $1.5 \mathrm{~d}$ & 10 \\
\hline Carpenters lead & $3 \mathrm{~d}$ & 9 \\
\hline Colour paper & $1.5 \mathrm{~d}$ & 130 \\
\hline Safety ink well & $6 \mathrm{~d}$ & 4 \\
\hline Nigerian Note paper of 100 sheets & $1 /-$ & 2 \\
\hline \multicolumn{3}{|l|}{ Books } \\
\hline \multicolumn{3}{|l|}{ Yoruba voices } \\
\hline Nigerian reader III & $1 / 6$ & 23 \\
\hline Nigeria reader Primer II & $6 \mathrm{~d}$ & 34 \\
\hline Nigeria reader I & $3 \mathrm{~d}$ & 7 \\
\hline Nigeria reader & $1 /-$ & 21 \\
\hline Nigeria reader IV & $2 / 6$ & 7 \\
\hline Nigeria reader $\mathrm{V}$ & $3 /-$ & 16 \\
\hline Nigeria reader VI & - & \\
\hline Yoruba grammar & $2 /-$ & 11 \\
\hline First grammar & $6 \mathrm{~d}$ & 6 \\
\hline Handbook of English grammar & $2 /-$ & 11 \\
\hline English Bible & $2 /-$ & 3 \\
\hline Yoruba bible & $3 /-$ & 3 \\
\hline English prayer and Hymn book & $4 /-$ & 6 \\
\hline Primer Gesi & $1 / 3$ & 6 \\
\hline Qualog & $1 /-$ & 6 \\
\hline German dictionary & $2 / 6$ & 5 \\
\hline Raighroad Dictionary & $1 / 6$ & 1 \\
\hline Iwe Orin Yoruba & $2 / 6$ & 6 \\
\hline Iwe Adura & $2 / 5$ & 5 \\
\hline Counter book No9810 & $1 / 9$ & 6 \\
\hline Counter book 5235 & $2 / 6$ & 3 \\
\hline Note book No 5767 & $2 \mathrm{~d}$ & 22 \\
\hline Ifa & $2 /-$ & 1 \\
\hline
\end{tabular}




\begin{tabular}{|c|c|c|}
\hline Catechism by water & $6 \mathrm{~d}$ & 6 \\
\hline Catechism eko ihinrere & $6 \mathrm{~d}$ & 2 \\
\hline Catechism ti Ijo & $6 \mathrm{~d}$ & 5 \\
\hline Aye Akamara & $1 /-$ & 12 \\
\hline Oruka Igbeyawo & $1 /-$ & 5 \\
\hline Iroyin odun Maja & $2 /-$ & 16 \\
\hline Olodumare & $9 \mathrm{~d}$ & 31 \\
\hline Aribiloso & $3 \mathrm{~d}$ & 9 \\
\hline Oro ife toto & $6 \mathrm{~d}$ & 4 \\
\hline Table book & $6 \mathrm{~d}$ & 6 \\
\hline Suratu Yesufu & $1 /-$ & 4 \\
\hline Isiro owo lede Yoruba & $9 \mathrm{~d}$ & 18 \\
\hline Ojo ohun kekere & $6 \mathrm{~d}$ & 11 \\
\hline Ode's poem & $3 /-$ & 3 \\
\hline Pendulum & $3 /-$ & 3 \\
\hline Hygiene book & $1 /-$ & 11 \\
\hline New English reader IV & $2 /-$ & 4 \\
\hline New English reader V & $2 / 6$ & 7 \\
\hline Ready Reckner & $2 / 6$ & 2 \\
\hline Arithmetic Merchant & $6 \mathrm{~d}$ & 27 \\
\hline Exercise book & $3 \mathrm{~d}$ & 116 \\
\hline Fools cap paper & $1 \mathrm{~d}$ & 25 \\
\hline Official envelope & $1 / 2 \mathrm{~d}$ & 105 \\
\hline Commercial envelope & $1 / 4 \mathrm{~d}$ & 540 \\
\hline Blue ink & $3 d$ & 22 \\
\hline Black ink & $3 d$ & 13 \\
\hline Red ink & $3 \mathrm{~d}$ & 6 \\
\hline Ink powder & $3 \mathrm{~d}$ & 22 \\
\hline School chalk & $1 \mathrm{~d}$ & 144 \\
\hline
\end{tabular}

